\title{
THE CONTRIBUTION OF THE MORPHOMETRIC PARAMETERS OF AN HYDROGRAPHIC NETWORK TO THE INVESTIGATION OF THE NEOTECTONIC ACTIVITY: AN APPLICATION TO THE UPPER ACHELOOS RIVER.
}

\author{
Lykoudi E. ${ }^{1}$, Angelaki M. ${ }^{2}$ \\ ${ }^{1}$ Department of Geological Sciences, School of Mining Engineering and Metallurgy, National \\ Technical University of Athens, 9, Heroon Polytechneiou St., Athens, 15780, Greece,, \\ elykoudi@metal.ntua.gr \\ ${ }^{2}$ Southampton Oceanography Centre, School of Ocean \& Earth Science, University of \\ Southampton, European Way, Southampton SO14 3ZH, U.K., ma10@soton.ac.uk
}

\begin{abstract}
In this paper the relationship between the morphometric parameters of a drainage system and the neotectonic activity is investigated. The hydrographic network of the Upper Acheloos River was chosen as the study area. The whole network and especially its western-southwestern part appears to be in the rejuvenated stage of evolution, as it is concluded by the analysis of the parameters, associated with the shape and slope of the basins, and the slope of the respective streams. Furthermore, the shape of the drainage network and the structure of the basins suggest that not only the Alpine orogenesis but also the neotectonic activity controls the morphogenetic processes in the area
\end{abstract}

\section{INTRODUCTION}

The main channel of the Acheloos river was formed during the Middle-Upper Miocene after the tectonism of the 'Gavrovo' geotectonic zone. The drainage basin of the Upper Acheloos river (upstream Kremasta Lake), is made up of lithological formations that belong to the 'Gavrovo' and 'Pindos' geotectonic zones (Fig. 1). Synclines, anticlines and normal faults with directions NNW-SSE (Aubuin 1959) are mainly observed, together with strike-slip faults with varying directions from E-W to ENE-WSW. This tectonic activity was followed by numerous normal faults with directions from EW to ENE-WSW (I.G.R.S. - B.P. 1971, Lymberis 1987). Furthermore, a $45^{\circ}$ horizontal clock-wise rotational movement (Catherine et al. 1984), is observed in the area during the last $30 \mathrm{My}$ and is connected with the strike-slip faults.

The Upper Acheloos hydrographic network is a sixth-order network, including 1,195 first-order streams, 313 second-order streams, 76 third-order streams, 15 fourth-order streams, and 3 fifthorder streams. The type of the network is combined, sub-parallel according to Howard (1967), and in some parts dendritic and rectangle. The main stream shows a meander form. The structure of the Upper Acheloos drainage basin is 'monoclinal': in the western part the basins are relatively smaller and the number of streams is lower, while in the eastern part the basins are more extended and the number of streams higher (Lykoudi 2000).

\section{METHODOLOGY}

A number of 76 third-order drainage basins were used as a statistical sample in the processing of the morphometric parameters. The basins were classified according to Strahler (1964). The above selection is based on the fact that the third-order basins had sufficient time available to develop their characteristics, while still retain recent neotectonic features. 
The methodology followed in this study comprises three steps: a)Storing of geoinformation using G.I.S. (Arc/lnfo). The geological database was based on geological maps of the Institut of Geology \& Mineral Explorati ר, scale 1:50,000 (Aubouin 1961, 1972), bibliography, and fieldwork. The information used in the topographic and geomorphologic database development was obtained from the respective topographic maps, scale 1:50,000 (Hellenic Military Geographical Service, H.M.G.S.). b) Measurement of the area of 76 third-order basins and their grouping in six lithological groups (Table 1). c) Determination of the morphometric parameters for the above basins (Table 2).

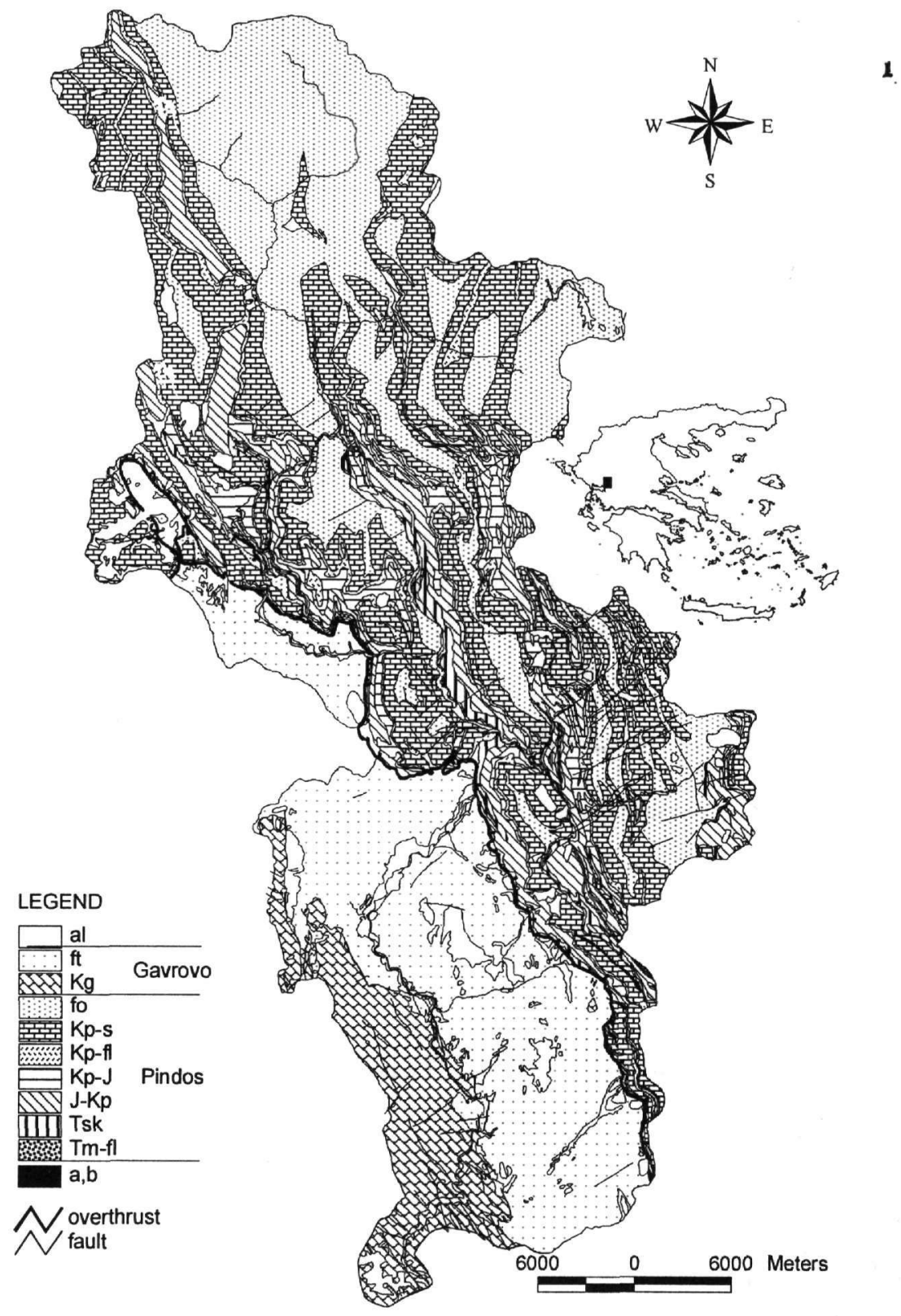

Figure 1. Geological map of the drainage basin* of the Upper Acheloos reaches al. Post-Alpine formations, 'Gavrovo zone'.: ft. flysch (Priabonian-Oligocene), Kg. limestones (Eocene), fo. flysch (Lower Paleocene- Eo- 
cene), Kp-s. limestones (Upper Cretaceous). 'Pindos zone', Kp-fl. first flysch (Lower Cretaceous), Kp-J. limestones with Calpionella (Upper Jurassic), J-Kp. cherts (Middle-Upper Jurassic), Tsk. Limestones and cherts (Upper Triassic-Lias), Tm-fl. clastic formation (Middle-Upper Triassic). a,b. igneous rocks (Lykoudi, 2000).

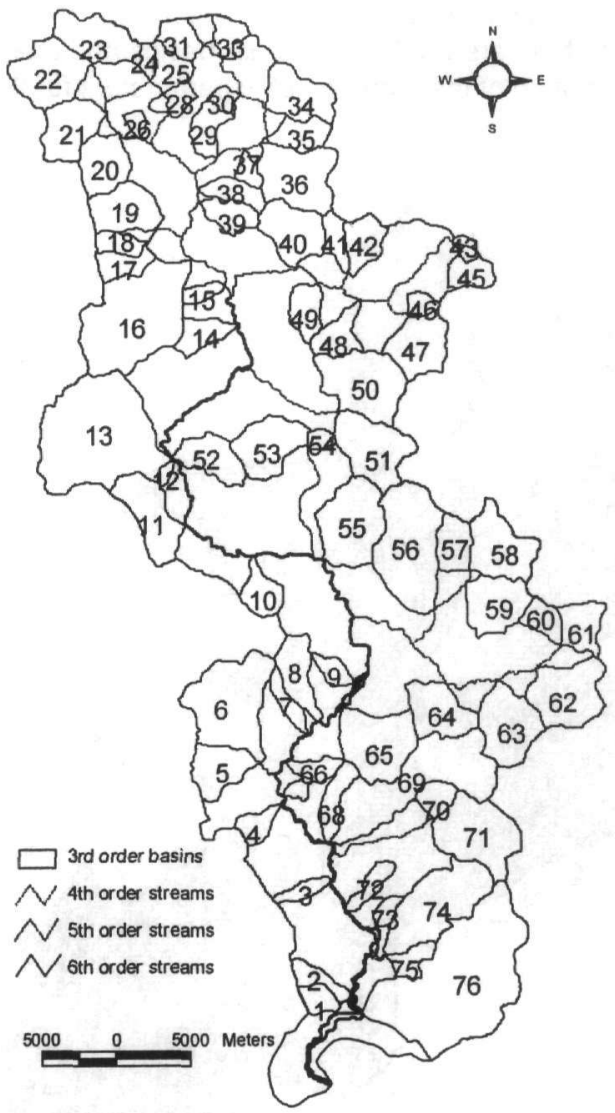

Figure 2. Third-order drainage basins of the Upper Acheloos reaches.

The evolution of the Upper Acheloos River hydrographic network follows the evolution of the relief of the area. This study is focused on the relationship between the network's features and the neotectonic activity in the surrounding area. In order to establish the above relationship, the following morphometric paralilıters were analysed: Elongation Ratio $\left(E_{u}\right)$, Circularity $\left(C_{u}\right)$, Lemniscate $\left(K_{u}\right)$, Relief Ratio $\left(R h_{u}\right)$ of the basins, Mean Axial Slope $\left(J k_{u}\right)$ of the streams.

Table 1. The lithological groups in the third-order drainage basins of the Upper Acheloos reaches.

\begin{tabular}{|c|c|c|}
\hline LITHOLOGICAL GROUPS & SYMBOL & THIRD-ORDER DRAINAGE BASINS \\
\hline GAVROVO FLYSCH & $f t$ & $5,6,7,8,9,10,66,67,68,72,73,74,75,76$ \\
\hline PINDOS FLYSCH & fo & $\begin{array}{l}15,24,25,26,27,28,29,30,31,3233,37,38, \\
39,43,46\end{array}$ \\
\hline GAVROVO LIMESTONES & $\mathrm{Kg}$ & $1,2,3,4$ \\
\hline PINDOS LIMESTONES OF CRETACEOUS & $K p-s$ & $12,21,22,42$ \\
\hline PINDOS LIMESTONES, PINDOS FLYSCH & $K p-s$, fo & $17,18,34,35,36,40,41,45,47,48,49,60,63$ \\
\hline $\begin{array}{l}\text { BASINS WITH MIXED LITHOLOGY } \\
\text { Flysch, Limestones, Cherts of 'Pindos' zone }\end{array}$ & $\begin{array}{l}f o, K p-s, K p-f l \\
K p-J, J-K p, T s k \\
T m-f l, a, b\end{array}$ & $\begin{array}{l}11,13,16,19,20,23,50,51,52,53,54,55,56,57,58 \\
, 59,61,62,64,65,69,70,71\end{array}$ \\
\hline
\end{tabular}


Table 2. Morphometric parameters

\begin{tabular}{|c|c|c|}
\hline Parameters & Formula & Bibliography \\
\hline Elongation Ratio, $\mathrm{E}_{\mathrm{u}}$ & $\begin{array}{l}\text { Diameter of a circle with an area equal } \\
\text { to the basin area / Length of the basin, } \\
E_{u}=d / L b_{u}=\left[2 \sqrt{ }\left(A_{u} / \pi\right)\right] / L b_{u}\end{array}$ & $\begin{array}{l}\text { Schumm, 1956, In: Gregory, J.K. et } \\
\text { al, (1973) }\end{array}$ \\
\hline Circularity, $C_{u}$ & $\begin{array}{l}\text { Area of the basin / Area of circle of the } \\
\text { same perimeter, } C_{u}=4 \pi A_{u} / P_{u}{ }^{2}\end{array}$ & $\begin{array}{l}\text { Miller, 1953, In: Gregory, J.K. et al, } \\
\text { (1973) }\end{array}$ \\
\hline Lemniscate, $K_{u}$ & $\mathrm{~K}_{u}=\mathrm{Lb}_{u}{ }^{2} / 4 A_{u}$ & $\begin{array}{l}\text { Chorley, Malm \& Pogorzelski, } 1957, \\
\text { In: Gregory, J.K. et al, (1973) }\end{array}$ \\
\hline $\begin{array}{l}\text { Mean Axial Slope of the } \\
\text { channel, } \mathrm{Jk}_{\mathrm{u}}\end{array}$ & $\mathrm{Jk}_{\mathrm{u}}=\left[\left(\mathrm{h}_{\max }-\mathrm{h}_{\min }\right) / \mathrm{I}_{\mathrm{s}}\right]^{*} 100$ & \\
\hline Relief Ratio, $\mathbf{R h}_{u}$ & $R h_{u}=H / L b_{u(\max )}$ & $\begin{array}{l}\text { Schumm, 1956, In: Gregory, J.K. et } \\
\text { al, (1973) }\end{array}$ \\
\hline $\begin{array}{l}\text { Where } \\
A_{u}=\text { Area of the basin } \\
L b_{u}=\text { Length of the basin } \\
P_{u}=\text { Perimeter of the basin } \\
h_{\max }=\text { Maximum altitude of } t \\
h_{\min }=\text { Minimum altitude of }\end{array}$ & \multicolumn{2}{|c|}{$\begin{array}{l}I_{s}=\text { Length of the channel } \\
H=\text { Local relief } \\
\left.L b_{u(\max )}\right)=\text { The maximum length of the basin, parallel } \\
\text { to the main watershed }\end{array}$} \\
\hline
\end{tabular}

The shape of the drainage basins is expressed by Elongation Ratio (Eu), Circularity (Cu) and Lemniscate $(\mathrm{Ku})$. The Elongation Ratio $(\mathrm{Eu})$ varies between 0 and 1.57 . The value 1.57 represents a basin of an ideal circular shape, while the zero value describes a fully elongated basin. Values higher than 0.8 refer to basins that show a low relief, while values lower than 0.8 are associated with basins of a steep relief (Fairbridge 1968). Hydrographic networks formed in elongated basins are closer to rectilinear type. The value of Circularity $(\mathrm{Cu})$ for quadrangular basins is approximately 0.8 and it decreases as the shape becomes more elongated. The ideal values of Lemniscate $(\mathrm{Ku})$ vary from 0.50 to 1.80 . For values between 0.50 and 0.32 the shape of the basin tends to be circular, while for values higher than 2 the drainage basin is fully elongated. The Mean Axial Slope (Jku) of the channel is an important parameter, used in the study of drainage basin equilibrium and hydrographic network geometry. It is an expression of the dynamic equilibrium among the tectonic activity, the erodibility of the substrate and the transport ability of the stream. The slope of the channel-bed gradually tends to a value, that permits an equilibrium between the weathering products and the material which is transported away (Strahler, 1950). The Relief Ratio (Rhu) is an expression of the slope of the drainage basins and indicates the intensity of erosion procedures.

\section{ANALYSIS OF THE MORPHOMETRIC PARAMETERS}

The interpretation of the rose diagrams for streams (Fig.3) and faults (Fig.4) results in the conclusion that older linear features, like streams and watersheds of higher order, follow Alpine geological structures (folds, normal faults with directions NW-SE), while younger features are associated with neotectonic structures, such as strike-slip faults and normal faults with varying directions from E-W to ENE-WSW, which cross-cut the Alpine ones. 

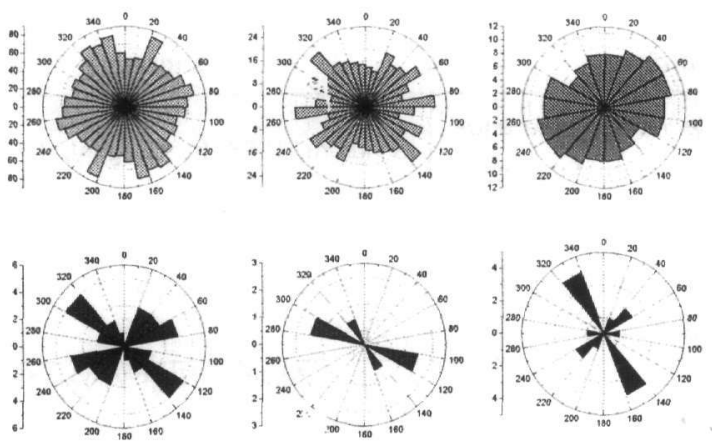

Figure 3. Rose diagrams for the streams of all classes (1st,2nd,3rd,4th,5th and 6th) of the Upper Acheloos basin.

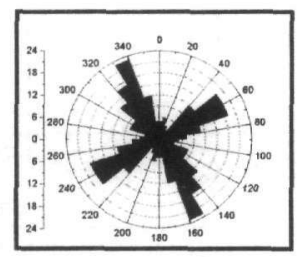

Figure 4. Rose diagrams for the faults of the Upper Acheloos basin.

The values of Elongation Ratio (Eu) for the third-order basins vary between 0.4 and 1.2 (Fig.5) and suggest an intermediate shape with a tendency to elongation. In the southwestern part (Valtos mountain) the basins show a fully elongated shape. The basins in the central part show a slight tendency to circular she:. e, while the northern basins show a stronger tendency to circularity. It is remarkable that the southeastern basins show an intermediate shape with a tendency to elongation, although the presence of loose lithological formations of 'Gavrovo' flysch, favours a more extended and circular shape of the basins. This indicates that in the present situation, the Elongation Ratio values are mainly controlled by exogenous procedures and only slightly by lithology. The elongated shape of the basins indicates a young stage of evolution, caused by intense neotectonic activity, while the intermediate shape with a tendency to circularity suggests an early mature stage.

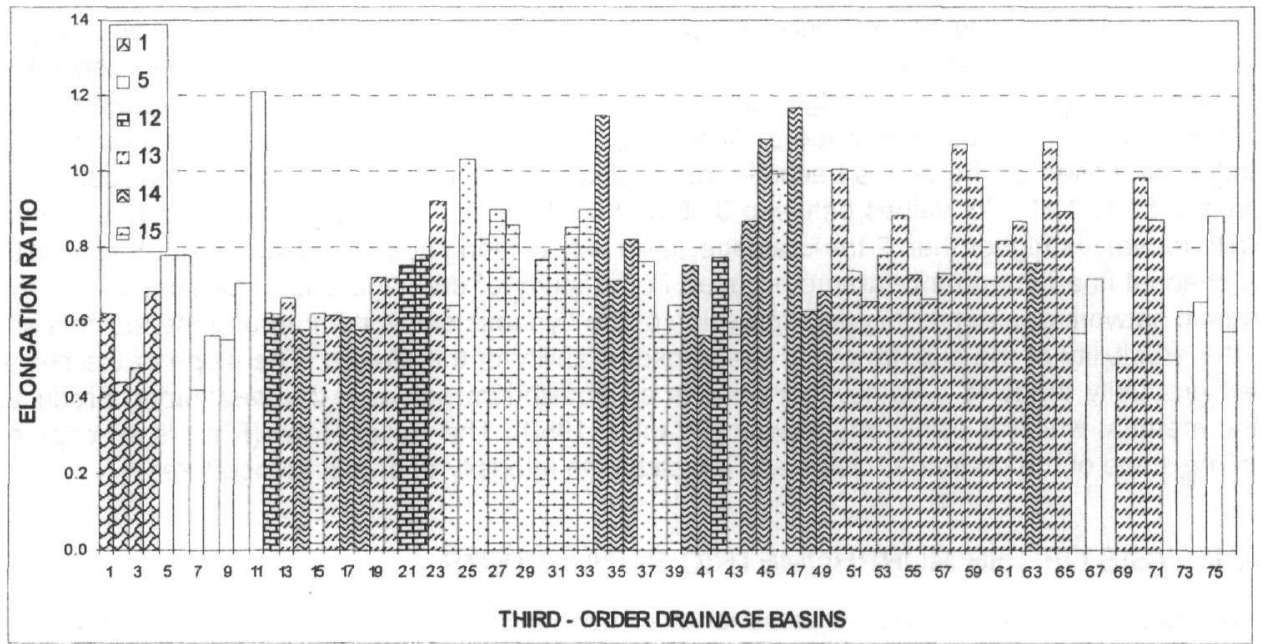

Figure 5. Elongation ratio of third-order drainage basins of the Upper Acheloos reaches for each lithological group. 1.Gavrovo flysch $(\mathrm{ft}) 5$. Gavrovo limestone $(\mathrm{Kg})$ 12.Pindos flysch (fo) 13.Pindos limestones (Kp-s) 14.Pindos limestones, flysch (Kp-s, fo) 15.Pindos limestones, chert, flysch (fo, Kp-s, Kp-fl, Kp-J, J-Kp, Tsk, Tm$\mathrm{fl}, \mathrm{a}, \mathrm{b})$.

The values of Circularity $\left(\mathrm{C}_{\mathrm{u}}\right)$ vary between 0.34 and 0.89 and their regional distribution follows the Elongation Ratio (Fig. 6). The shape of the basins can be approximated by an intermediate one with a tendency to elongation, with the exception of some basins that show a more circular shape. The observed combination of high Elongation Ratio and Circularity values, especially in the 
northern and eastern part, can be explained by the complicated and polygonal shape of the basins. The complicated shape is the result of: a) tectonic structure b) the presence of alternating lithological formations, leading to differential erosion and consequently to watershed displacement.

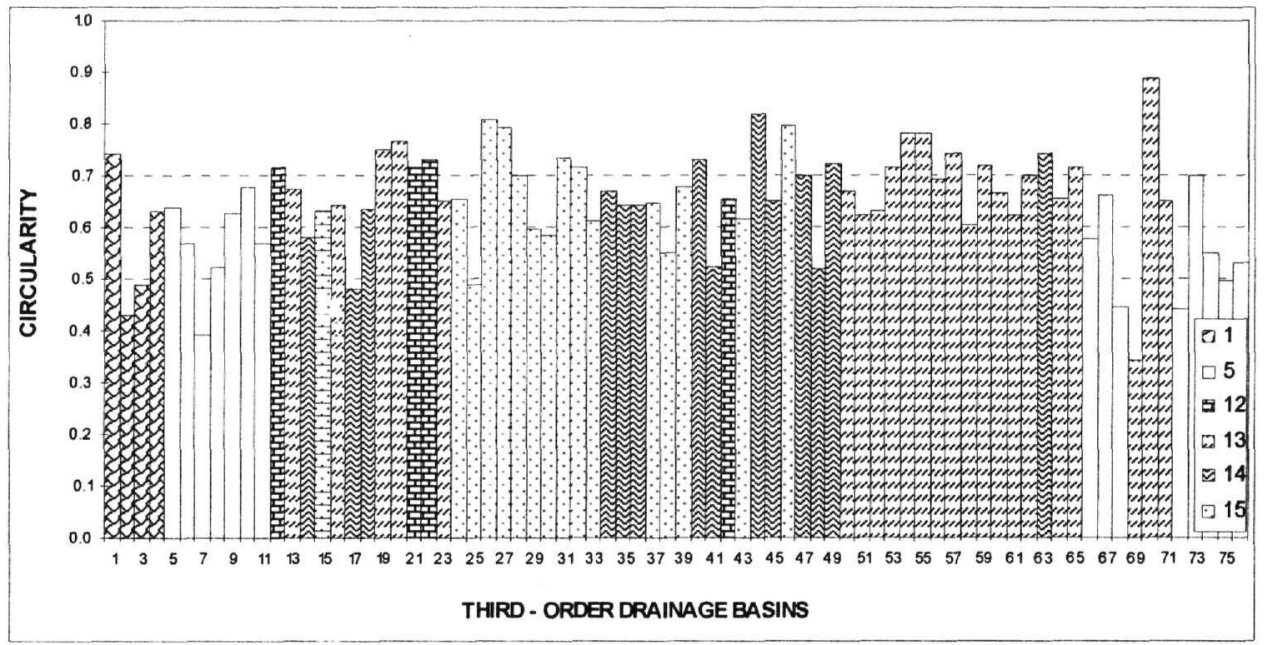

Figure 6. Circularity of third-order basins for each lithological group (See legend in Fig. 5).

The values of Lemniscate $\left(K_{u}\right)$ vary between 0.24 and 1.77. Most of the third-order basins, especially those in the southern and southwestern part, exhibit high Lemniscate values, which suggests a tendency to elongation. This indicates that the basins belong to a young stage of evolution, consequently they have not reached the ideal 'drop' shape. The observed grouping of Lemniscate values according to lithology (Fig. 7) indicates that lithology is an important factor in the evolution of the basins, particularly $: \because$ cases where neotectonic activity is not really intense. The evolution rate depends on the lithology, e.g. rocks, highly resistant to erosion procedures, impose a very slow evolution.

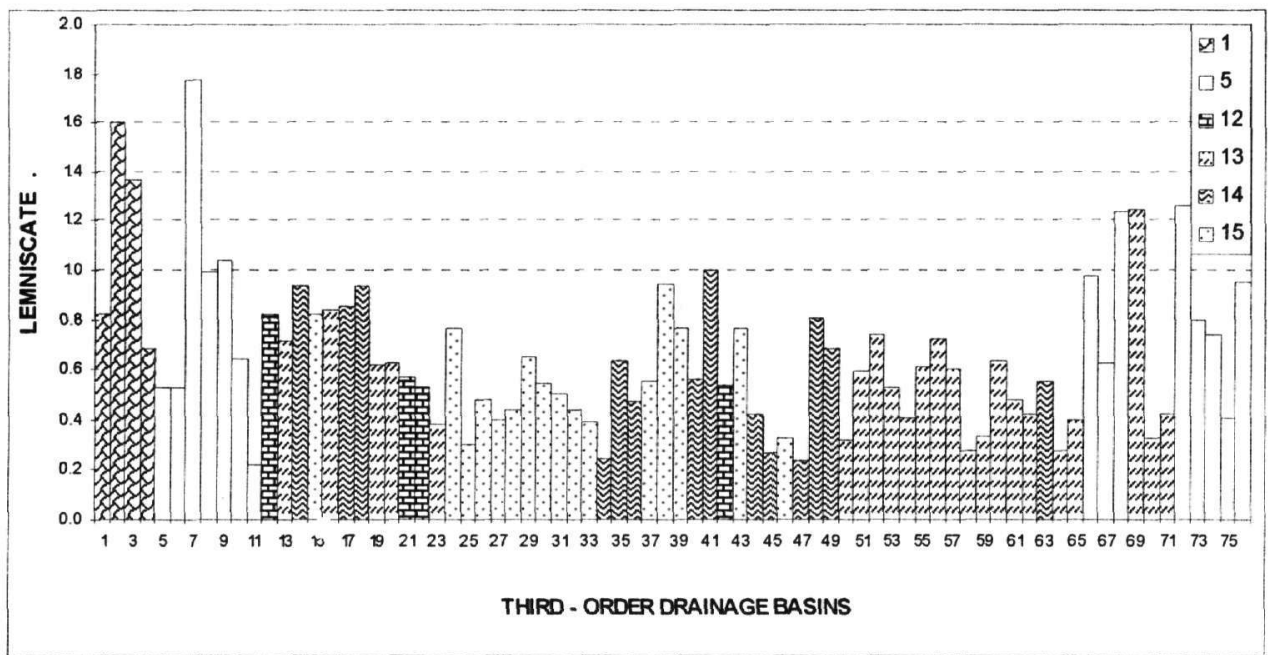

Figure 7. Lemniscate values of third-order basins for each lithological group (See legend in Fig. 5). 
The values of the Mean Axial Slope ( $\mathbf{J k}_{\mathrm{u}}$ ) of the channels vary between $1.16 \%$ and $45.68 \%$. The observed grouping of values according to lithology (Fig. 8) confirms that lithology plays an important role on this parameter. The highest values are observed mainly in the southwestern and northern part of the investigated area due to neotectonic uplift of these areas and lithology, which permits the preservation of steep slopes. The lowest values of Mean Axial Slope of channel beds are observed in the sou' ''-southeastern and central drainage basins, which are dominated by more erodible rocks ('Gavrovo' flysch and mixed lithological formations respectively). Different values are observed between basins of similar lithology ('Gavrovo' flysch and 'Pindos' flysch) because: a) the lithological formations of 'Pindos' zone have undergone a much stronger tectonic strain, so they introduce a steeper relief comparatively to 'Gavrovo' zone b) the two flysches are of different composition, as the 'Pindos' flysch is dominated by sandstones and marls, and 'Gavrovo' flysch by conglomerates.

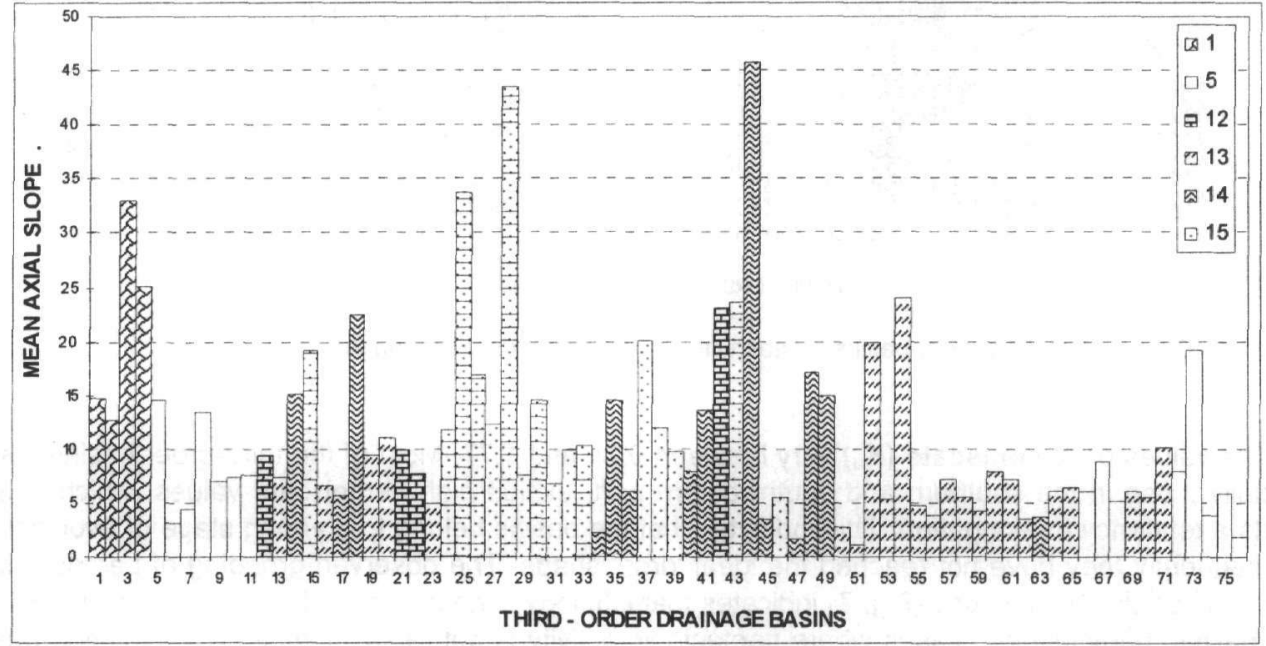

Figure 8. Values of Mean Axial Slope of the third-order channel beds for each lithological group (See legend in Fig. 5).

The Relief Ratio $\left(\mathbf{R} \mathbf{h}_{\mathrm{u}}\right.$ ) (or mean surface slope) of the third-order drainage basins varies between the values of $4.7 \%$ and $43.6 \%$ (Fig. 9). Basins consisting of 'Gavrovo' limestones show high values of Relief Ratio, while basins made up of 'Pindos' limestones and flysch exhibit lower values. The lowest values are observed in drainage basins with 'Gavrovo' flysch and mixed lithological background, indicating that strong erosional procedures took place in the past. The high values of Relief Ratio and Mean Axial Slope in the southwestern part, can be explained by the neotectonic activity (uplift) in the ar: $: a$ and the presence of highly resistant rocks ('Gavrovo' limestones). It is remarkable that basins with 'Gavrovo' flysch show values of Relief Ratio, which are higher in the western part than the eastern part due to neotectonic processes and continuous uplift of the area. 


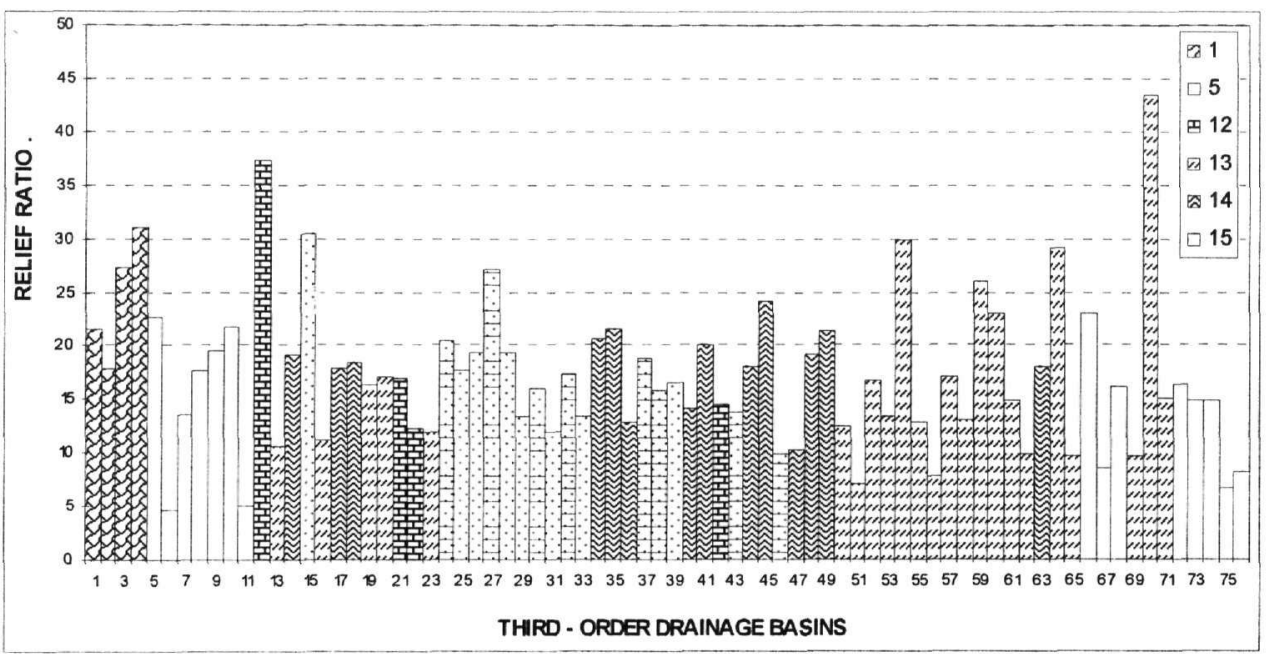

Figure 9. Relief ratio of third-order drainage basins for each lithological group (See legend in Fig. 5).

\section{DISCUSSION - CONCLUSIONS}

The evolution of the Upper Acheloos hydrographic network is associated with the evolution of the relief of the area. The data processing and analysis of the linear features of the streams result in the conclusion that different linear features (tectonic, lithological or morphological features) show the same direction or coincide. This suggests that both the Alpine folding and neotectonic activity still control the morphogenetic processes of the investigated area. Therefore, the older linear features (streams and watersheds of higher order) show directions that follow or coincide with the directions of the Alpine folding, suggesting that they have been formed during the Alpine orogenesis and still retain the above effect. The flow direction of younger streams (channels of lower order) is mainly controlled by younger faults, which have been reactivated during Pleistocene and they show directions from E-W to ENE-WSW and NW-SE as well.

The drainage basin of the Upper Acheloos River belongs to a rejuvenated stage of evolution (uplift), as it is concluded $k$ !' the combination of the following: a) the third order drainage basins show an intermediate shape (with a tendency either to the elongation for the southern basins or to circularity for the northern ones), suggesting that they belong to a young or early mature stage, b) the Mean Axial Slope of the channels and Relief Ratio of the drainage basins exhibit medium-high values.

The elongation observed in the southern basins could be explained by the extension-tectonism which dominates the southern part of the network, while in the northern part the extension is much less obvious than the uplift (circular basins). The intense extensive field in the south causes the uplift movement of the Gavrovo mountain in the southwestern part relatively to the southeastern part, which is characterized by pure expansion. Both parts, southeastern and southwestern show elongated type of basins. In the north the extension is not so intense and combined with the erodible lithology (Pindos flysch) gives basins with a tendency to circularity.

The monoclinal structure of the drainage basin and the limited number of streams in the western part comparatively to the eastern part, can be explained by the displacement of the main channel of the river to the west. This displacement was interrupted due to intense uplifting movements in the western-southwestern part and the presence of erosion-resistant rocks ('Gavrovo' limestones). The displacement was caused by the following: a) The E-W to ENE-WSW strike-slip faults, associated with the horizontal clockwise rotation of the area, interrupted the main channel course of a NW-SE direction and displaced rertain parts of it to the west along an east-west direction. This resulted in a meandering shape of the channel. The displacement gradually increases from north to south. b) The investigated area exhibits an extension- tectonism along a NW-SE direction. 
The above asymmetric structure, which is basically caused by extension- tectonism, is responsible for the large area nbserved in the basins of the eastern und mainly southeastern part, relatively to the western part.

As a conclusion, the analysis of the morphometric parameters of a hydrographic network provides valuable information about the neotectonic procedures and their impact on the evolution of the drainage basins.

\section{REFERENCES}

Aubouin, J., (1959): Contril" 'tion à l' étude géologique de la Gréce septentrionale: les confins de l' Epire et de la Thessalie. Thèse, sciences, Univ. Paris, 1958 et Ann. géol. Pays hellén., 10, 1-525, Athènes.

Aubouin, J., (1961): I.G.M.E. geological map, 1:50,000, sheets: Pramanta, Kastanea

Aubouin, J., (1972): I.G.M.E. geological map, 1:50,000, sheet Kalampaka.

Catherine, K., Laj, C., \& Muller, C., (1984): Tertiary geodynamical evolution of northwestern Greece: paleomagnetic results. Earth and Planetary Science Letters, 72 (1985), pp. 190-204, Amsterdam.

Fairbridge, R., (1968): Encyclopedia of Geomorphology. Encyclopedia of earth sciences series, volume III. Dowden, Hutchingon \& Ross, Inc. Stroudsburg, Pennsylvania, United States of America.

Gregory J.K., Walling, E.D., (1973): Drainage Basin Form and Process. A geomorphological approach. Edward Arnold (publ.) Ltd., London.

Hellenic Military Geograpt i:al Service, (H.M.G.S.): Topographical maps, scale 1:100,000, sheets: Metsovo, Karditsa, Peta, Trikala.

Howard, A. D. (1965): Geomorphological systems - equilibrium and dynamics. Am. J. Sci., 263:302-312.

I.G.R.S. - B.P., (1971): Institut de Geologie et Recherches du Sous-sol et Britisch Petroleum Ltd. Co, AthenesLondres.The geological Results of Petroleum Exploration in Western Greece. Athens, I.G.R.S.,No 10.

Lymberis, N., (1987): Geodynamique du domaine égéen depuis le Miocène supérieur. PhD Thesis. Mém. Sc. Terre Univ. Curie, Paris.

Lykoudi, E. (2000): Geomorphological evolution of the Upper Acheloos drainage basin. PhD Thesis. Mining \& Metallurgy Engineering Dept., National Technical University of Athens, p.123-215.

Strahler, A., (1950): Equilibrium theory of erosional slopes approached by frequency distribution analysis. Am. J. Sci., 248:673-696, $800: 14$.

Strahler, A., (1964): Quantitative geomorphology of drainage basins and channel networks. In: Chow, V. (ed.) Handbook of applied hydrology. Section 4-II, p. 39-76. Mc Graw-Hill Book Co., New York. 